\title{
ARL Salary Survey
}

The Association of Research Libraries (ARL) recently released its 1977-78 Annual Salary Survey. Compiled by Associate Executive Director Suzanne $O$. Frankie, the new report includes data assembled from ninety-four university library members and eleven nonuniversity library members.

Salary figures in the tables indicate that for 1977-78 librarians did little more than break even in terms of real purchasing power, and 1978-79 projections show that librarians will probably experience a 2.9-percent decline in purchasing power

\section{Closed Collection}

The Celtic Library, a special collection housed at the College of St. Thomas in St. Paul, Minnesota, is presently being cataloged. Many Celtic records are being entered into the OCLC - data base. The Celtic Library is a closed collection and items in it are not available for interlibrary loan. Please do not request Celtic-related items from St. Thomas on interlibrary loan.
Basic tables in the survey show average, median, and beginning professional salaries for ARL libraries. Beginning salaries at university libraries for 1978-79 range from $\$ 9,000$ at the University of Southern California to $\$ 16,500$ at the University of British Columbia.

Supplementary tables have permitted a number of different analyses, and among the findings Frankie points out that of the filled professional positions, 62 percent are held by women and 38 percent by men. As shown in other surveys, there are imbalances in the distribution of staff by sex, with most of the top administrative posts held by men. The average salary for men is higher than that for women in fifteen of the nineteen position categories used.

Except for top administrators, librarians in public institutions earn higher average salaries than do librarians in private schools, and with few exceptions the bigger libraries pay more than the smaller ones. In general, librarians in the Pacific region earn the most while librarians in the East South Central region earn the least.

Copies of the survey are available from the Association of Research Libraries, 1527 New Hampshire Ave., N.W., Washington, DC 20036, for $\$ 5$.

\section{Has popularity misplaced your November 15th issue?}

Demco pamphlet cases help prevent the November 15th or any popular back issue from being filed in the wrong stack. Keep all your magazines neatly organized for faster location and convenient refiling with these tough plastic storage files. Available in cut-corner, open back or Princeton styles. pamphlet cases have bright colors that give decorator accents to your periodical area or allow arrangement by color-coding. Cardboard versions help keep magazines dust-free or add visibility and organization at an economical price.

Specially designed for libraries, all our magazine storage and display products protect your popular magazines from disorganization and wear. Check pages 104-115 in your new Library Supplies \& Equipment Catalog for the perfect answer. If you don't have a copy, write for this complete library shopping guide today.

\section{DEMCO}

Your Library Specialist

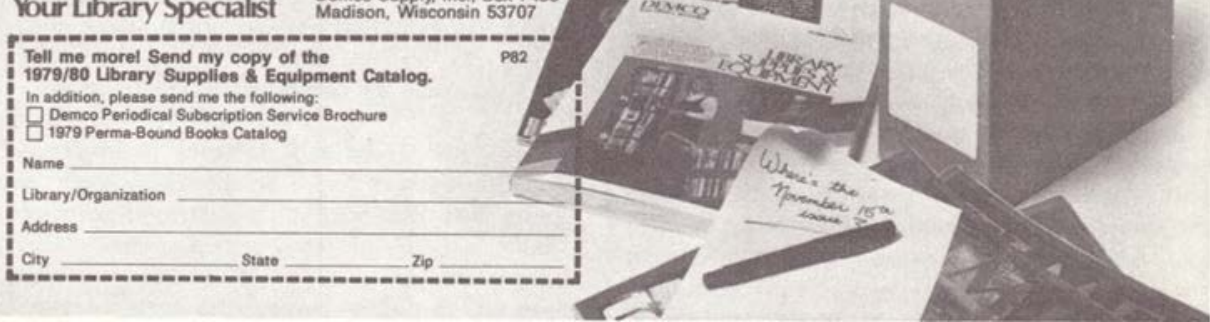

